\title{
Physico-chemical Analysis of Pravara River water and its Impact on Human Health in Sangamner Tahashil (Maharashtra)
}

\author{
Dr. Sangita Dandwate
}

Department of Chemistry, S.M.B. S.T College Sangamner, Ahmednagar, Maharashtra, India

\section{Article Info}

Volume 7, Issue 6

Page Number: 358-365

Publication Issue :

November-December-2020

\section{Article History}

Accepted : 10 Dec 2020

Published : 24 Dec 2020

\section{ABSTRACT}

Water samples were collected from five different stations during pre monsoon season in Sangamner tahasil, Ahmednagar district. Different physicochemical parameters were measured and the samples were also analysed. Physicochemical parameters included $\mathrm{pH}$, temperature, total alkalinity, total dissolved solids, electrical conductance (EC) bicarbonate, calcium, magnesium, Sodium etc. The quality of water play an important role concern to human being. Water covers 71\% of Earth's surface and is vital for all known forms of life Only 2.5\% of the Earth's water is fresh water, and $98.8 \%$ of that water is in ice and groundwater. Natural water, whether in the atmosphere, on ground surface, or under the ground, always contains dissolved minerals and gases as a result of its interaction with the atmosphere, minerals in rocks, organic matter, and living organisms. Reservoirs are one of the most important water resources used for water supply and irrigation. The results obtained from chemical analysis were compared with three standards namely BIS, WHO and ISI. Effect of industrial waste, municipality sewage and agriculture runoff on the river water were investigated. It is found that this water body is not suitable for drinking .so possible remedial methods should be adopted for this water resource for improving its quality.

Keywords : Physico -chemical analysis, Pravara river , water quality, Industrial waste, agriculture runoff

\section{INTRODUCTION}

The increasing industrialization, urbanization and developmental activities and consequent pollution of water is of major concern. Today most of the rivers of world receive millions of litrs of sewage, industrial and agricultural leachates containing substances varying in characteristics from simple nutrients to highly toxic / hazardous substances. The fate of ground waters is also same in most of the areas. The cities and industries continue to be the most significant causes of pollution of aquatic ecosystems due to a diverse kind of wastes produced (Trivedy and Goel, 1984). The pollution problems in industrial 
areas are significant. Temperature, $\mathrm{PH}$, turbidity, electrical conductivity, are the most important physico-chemical properties of water (APHA1992)

Hydrochemistry is an important aspect of ground water in order to know its use for domestic irrigation and Industrial purpose .Analysis of water and its interpretation and assessment will determine the various uses of ground water Soil and water are important abiotic factor of environment. Water is the most vital resource for all kinds of life on the planet, adversely affected both qualitatively and quantitatively by human activities on land, in air or in water.

Therefore, the main objects of the study to water samples were analysed. The physico-chemical parameters viz hardness, amount of various ions in water, $\mathrm{pH}$, chloride, carbonate, bicarbonate, sodium, calcium, magnesium. Seven water samples from ten different sites were analysed.

Table 1. Sampling station in Pravara river

\begin{tabular}{|l|l|l|}
\hline $\begin{array}{l}\text { Sampling } \\
\text { site no. }\end{array}$ & $\begin{array}{l}\text { Location } \\
\text { sampling sites }\end{array}$ & Description \\
\hline I & $\begin{array}{l}\text { Sangvi near the } \\
\text { bank of pravara }\end{array}$ & $\begin{array}{l}\text { Agricultural runoff } \\
\text { sources }\end{array}$ \\
\hline II & $\begin{array}{l}\text { On the way of } \\
\text { pemgiri }\end{array}$ & $\begin{array}{l}\text { Agricultural runoff } \\
\text { sources }\end{array}$ \\
\hline III & $\begin{array}{l}\text { Near datta } \\
\text { temple }\end{array}$ & $\begin{array}{l}\text { Domestic wastes and } \\
\text { Agricultural runoff } \\
\text { sources }\end{array}$ \\
\hline IV & Gavali mala & $\begin{array}{l}\text { Agricultural runoff } \\
\text { sources }\end{array}$ \\
\hline V & Pravara pul & $\begin{array}{l}\text { Domestic wastes and } \\
\text { Agricultural runoff } \\
\text { sources mulcipality } \\
\text { waste car and } \\
\text { animal wash } \\
\text {,industrial waste }\end{array}$ \\
\hline
\end{tabular}

\begin{tabular}{|l|l|l|}
\hline VI & $\begin{array}{l}\text { Near Rajhanse } \\
\text { dairy }\end{array}$ & $\begin{array}{l}\text { Industrial waste , car } \\
\text { and animal wash, } \\
\text { Domestic waste } \\
\text { sources }\end{array}$ \\
\hline VII & Paper mill area & $\begin{array}{l}\text { Industrial waste , car } \\
\text { and animal wash, } \\
\text { Domestic waste } \\
\text { sources }\end{array}$ \\
\hline VIII & Velhale village & $\begin{array}{l}\text { Agricultural runoff } \\
\text {,Domestic } \\
\text { sources waste }\end{array}$ \\
\hline IX & $\begin{array}{l}\text { On the way of } \\
\text { Rajapur }\end{array}$ & $\begin{array}{l}\text { Industrial waste , car } \\
\text { and animal wash, } \\
\text { Domestic waste } \\
\text { sources }\end{array}$ \\
\hline X & $\begin{array}{l}\text { Near Agneshwar } \\
\text { temple }\end{array}$ & $\begin{array}{l}\text { Industrial waste , car } \\
\text { and animal wash, } \\
\text { Domestic waste } \\
\text { sources }\end{array}$ \\
\hline
\end{tabular}

\section{METHODS AND MATERIAL}

Sangamner area is located in the northern part of the Ahmednagar district of Maharashtra State. The Sangamner tahsil lies between 180 36' N and 1901' N latitude and between 740 1' $\mathrm{W}$ and 740 56' W longitude

The Sangamner town is located on the confluence streams of Pravara and the Mhalungi rivers, which is at a distance of $150 \mathrm{~km}$ from Pune, on Pune-Nasik National Highway No. NH-50. The area is drained by the Pravara river, which originates in the hilly region of Western Ghats at Ratangarh. Geologically, basalts underlay the Pravara basin.In general the climate is dry and hot the average maximum temperature during summer is as high as $42^{\circ} \mathrm{C}$ in month of May and average minimum temperature falls up to $10^{\circ} \mathrm{C}$ during the month of December., annual rainfall ranging from 290 to $594 \mathrm{~mm}$. 
The water samples were collected randomly from ten different stations during pre monsoon season. In the present study, water samples were collected from ten different locations of Pravara river of Sangamner city in Ahemednagar district ., namely S-I (Sangvi near the bank of Pravara ), S-II (On the way of pemgiri), SIII (Near datta temple), S-IV (Gavali mala ), S-V (Pravara pul), S-VI (Near rajhanse dairy ) S-VII (Paper mill area) ,S-VIII (Velhale village) ,S-IX (On the way of rajapur ) S-X (Near Agneshwar temple ) for physico-chemical analysis. Water samples were collected from sampling sites pre monsoon, ( WHO 2004,2009)

The water samples were brought for the estimation of various Physical and chemical parameters . Physical parameters tested were $\mathrm{pH}$, temperature, colour and turbidity rabidity should be less than 5.0 Nephelometric Turbidity Units and pH should be less than 8 Chemical parameter electrical conductivity, Total Dissolved solids (TDS), calcium, magnesium , carbonate, bicarbonate sodium and chloride. The $\mathrm{pH}$ and turbidity were measured and estimated at sampling sites by using water analysis kit.

For physico-chemical analysis, water samples were collected in one litre polyethylene bottle.

\section{Determination of water quality parameters}

The analysis of various physico-chemical parameters namely $\mathrm{pH}$, Temperature, Turbidity, Colour, Total Dissolved Solids (TDS), Total Hardness (TH), Calcium Hardness, magnesium and Alkalinity. The standard methods APHA et al (1995) were adopted for analysis of water. Temperature and $\mathrm{pH}$ were measured at the time of sampling itself.

The standard limits of water quality parameters in drinking water prescribed by WHO, BIS , ISI, ICMR, and is shown in the Table 2

Table 2. The standards for physical and chemical quality of drinking water.

\begin{tabular}{|l|l|l|l|l|l|l|l|l|}
\hline Water parameter & \multicolumn{2}{|l|}{ WHO } & \multicolumn{2}{l|}{ BIS } & \multicolumn{2}{l|}{ ISI } & \multicolumn{2}{l|}{ ICMR } \\
\hline & HDL & MPL & HDL & MPL & HDL & MPL & HDL & MPL \\
& & & & & & & & \\
\hline $\mathrm{P}^{\mathrm{H}}$ & $7-8$ & $6.5-9.5$ & $7.0-8.3$ & $8.5-9.0$ & $6.5-8.5$ & $8.5-9.5$ & $7.0-8.5$ & $6.5-9.2$ \\
\hline Temp.0 0 c & - & - & - & - & - & - & - & - \\
\hline Turbidity(NTU) & 5 & 25 & 5 & 10 & 10 & 25 & 5 & 10 \\
\hline colour & - & - & - & - & - & - & - & - \\
\hline TDS mg-1 & 500 & 1500 & 500 & 2000 & 500 & 1500 & 500 & 2000 \\
\hline Calcium (mg/L) & 75 & 200 & - & -- & 75 & 200 & - & - \\
\hline Magnesium(mg/L) & 30 & 150 & - & - & 30 & 100 & - & - \\
\hline TH (mg/L) & 100 & 500 & 200 & 600 & 300 & 600 & 300 & 600 \\
\hline Alkalinity (mg/L) & 200 & 600 & 175 & 550 & 200 & 600 & - & - \\
& & & & & & & & \\
\hline
\end{tabular}

MPL ( Maximum permissible limit), HDL ( Highest Desirable level), ISI ( Indian Standard Institute ), ICMR ( Indian Council of Medical Research), BIS ( Bureau of Indian Standard ), WHO( World Health Organization). 
Dr. Sangita Dandwate Int J Sci Res Sci \& Technol. November-December-2020; 7 (6) : 358-365

Table 3 : Analysis of various physic- chemical parameters at sampling sites

\begin{tabular}{|c|c|c|c|c|c|c|c|c|c|c|}
\hline Parameter & Colle & ion stat & & & & & & & & \\
\hline & S-I & S-II & S-III & S-IV & S-V & S-VI & S-VII & S-VIII & S-IX & S-X \\
\hline $\mathrm{P}^{\mathrm{H}}$ & 7.82 & 8.27 & 8.17 & 8.15 & 8.31 & 8.45 & 8.7 & 8.19 & 8.55 & 8.39 \\
\hline Temp. ${ }^{0} \mathrm{C}$ & 28.5 & 29.7 & 28.2 & 26.6 & 28.6 & 28.7 & 29.2 & 30.1 & 29.4 & 28.9 \\
\hline Turbidity & 3.5 & 4.3 & 5.9 & 5.2 & 5.6 & 3.9 & 5.5 & 5.6 & 6.4 & 5.5 \\
\hline Colour & clear & clear & clear & clear & clear & clear & brown & clear & brown & brown \\
\hline $\mathrm{EC} \mathrm{dSm}-^{-1}$ & 0.65 & 0.69 & 2.94 & 3.67 & 0.85 & 1.89 & 2.46 & 2.2 & 1.26 & 1.26 \\
\hline $\mathrm{TDS}_{\mathrm{mg}}{ }^{1}$ & 416 & 443.7 & 1883 & 2348.8 & 544 & 1121 & 1469 & 1408 & 804.3 & 780.9 \\
\hline $\mathrm{CO}_{3}{ }^{2-} \mathrm{me}^{-1}$ & $\mathrm{Ab}$ & $\mathrm{Ab}$ & $\mathrm{Ab}$ & $\mathrm{Ab}$ & $\mathrm{Ab}$ & $\mathrm{Ab}$ & $\mathrm{Ab}$ & $\mathrm{Ab}$ & $\mathrm{Ab}$ & $\mathrm{Ab}$ \\
\hline $\mathrm{HCO}_{3} \mathrm{me}^{-1}$ & 11.2 & 8.37 & 4.77 & 4.33 & 11.4 & 3.4 & 16.2 & 15.9 & 4.23 & 4.97 \\
\hline $\mathrm{Ca}^{++} \mathrm{me}^{-1}$ & 7.63 & 8.36 & 7.06 & 9.43 & 11.4 & 4.97 & 14.1 & 15.5 & 12.3 & 4.83 \\
\hline $\mathrm{Mg}^{++} \mathrm{me}^{-1}$ & 12.3 & 3.33 & 7.43 & 7.93 & 4.53 & 5.5 & 12.83 & 5.77 & 5.83 & 9.07 \\
\hline $\mathrm{Na}^{+} \mathrm{me}^{-1}$ & 9.86 & 12.19 & 39.19 & 39.87 & 27.4 & 16.1 & 23.08 & 14.34 & 16.71 & 13.71 \\
\hline $\mathrm{Cl}-\mathrm{me}^{-1}$ & 13.8 & 9.36 & 18.6 & 35.3 & 14.7 & 28.1 & 25.63 & 16.9 & 16.87 & 13.9 \\
\hline
\end{tabular}

\section{RESULTS AND DISCUSSION}

\section{1. $\mathrm{pH}$}

As per BIS $\mathrm{pH}$ of drinking water should be between 6.5 to 8.5 If the $\mathrm{pH}$ of water goes below 6.5 to 8.5 leads to harmful effects. Maximum $\mathrm{p}^{\mathrm{H}}$ (8.27) and (8.31) found in water sample collected from S-II and S-V. while lower in S-I( 7.82 ), S-III(8.17) and S$\mathrm{IV}(8.15)$ It is observed that, the $\mathrm{p}^{\mathrm{H}}$ of water remain alkaline The variation in $\mathrm{pH}$ of irrigation water were associated with source, quality and quantity of irrigation water used, types and quantity of fertilizer added and cropping pattern followed WHO, BIS , ISI, ICMR proposed at desirable range of 6.5 to 8.5 for $\mathrm{pH}$ of drinking water ( BIS,1991,2004,2005) but greater than 8.6 except S- VII and S- X Sampling sites $\mathrm{pH}$ is one of the most important operational water quality parameters. The value of $\mathrm{pH}$ at ten sampling sites are shown in fig 1.

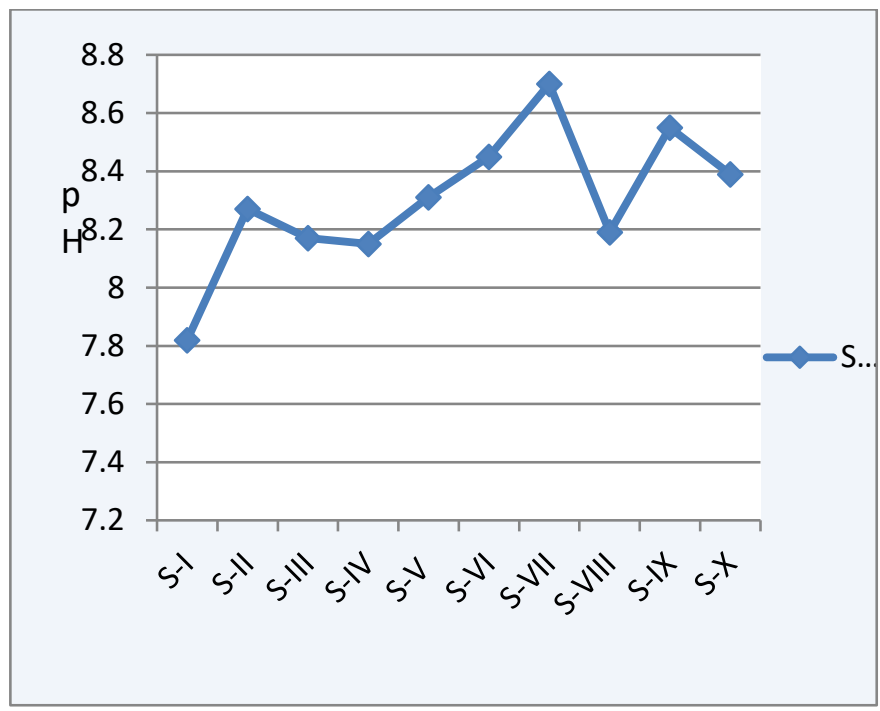




\section{Temperature}

The temperature values at ten sampling sites are shown in fig 2. The temperature of collected water samples varies in between 28 to $30{ }^{\circ} \mathrm{C}$ at all water sampling sites pre monsoon. No health based guidelines are proposed for temperature by WHO, BIS, ISI, ICMR.

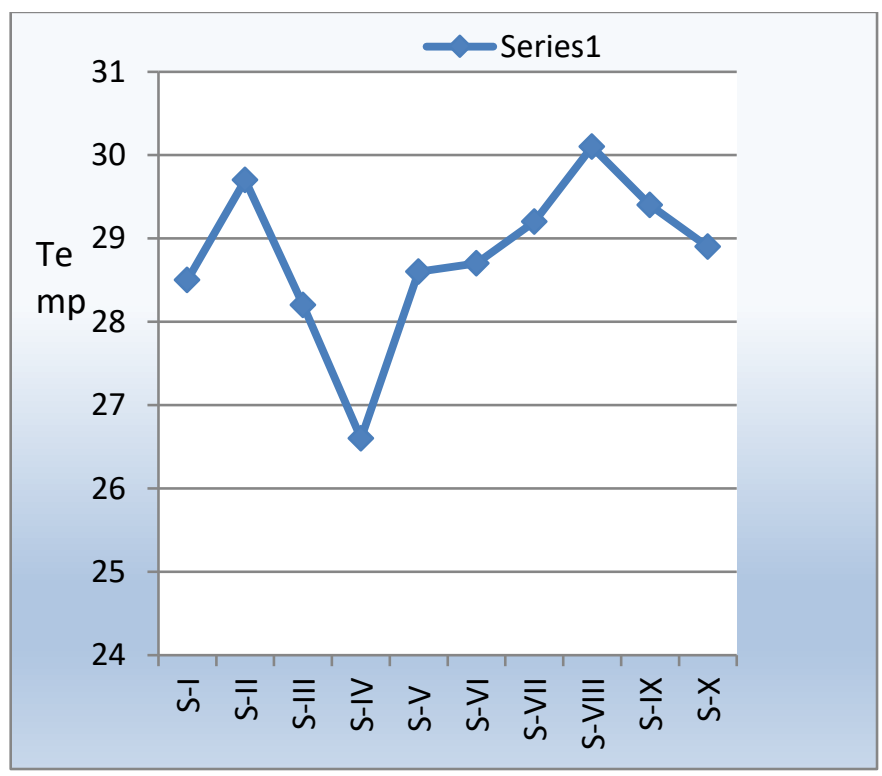

\section{Turbidity}

The turbidity values at ten sampling sites are shown in table 3. No health based guidelines are proposed for temperature by WHO, BIS, ISI, and ICMR. The temperature of collected water samples varies in between 5 to 10 at all water sampling sites pre monsoon.

\section{Colour}

The water samples are generally coloured due to presence of colloidal , inorganic ,impurity, decomposition of vegetation. The water samples collected was found to be colourless and some are brown colour because of industrial effluent percolate well.

\section{Electrical conductivity}

The electrical conductivity of water were low and within safe limit (1.75 dSm-1). The electrical conductance values at ten sampling sites are shown in fig 3.

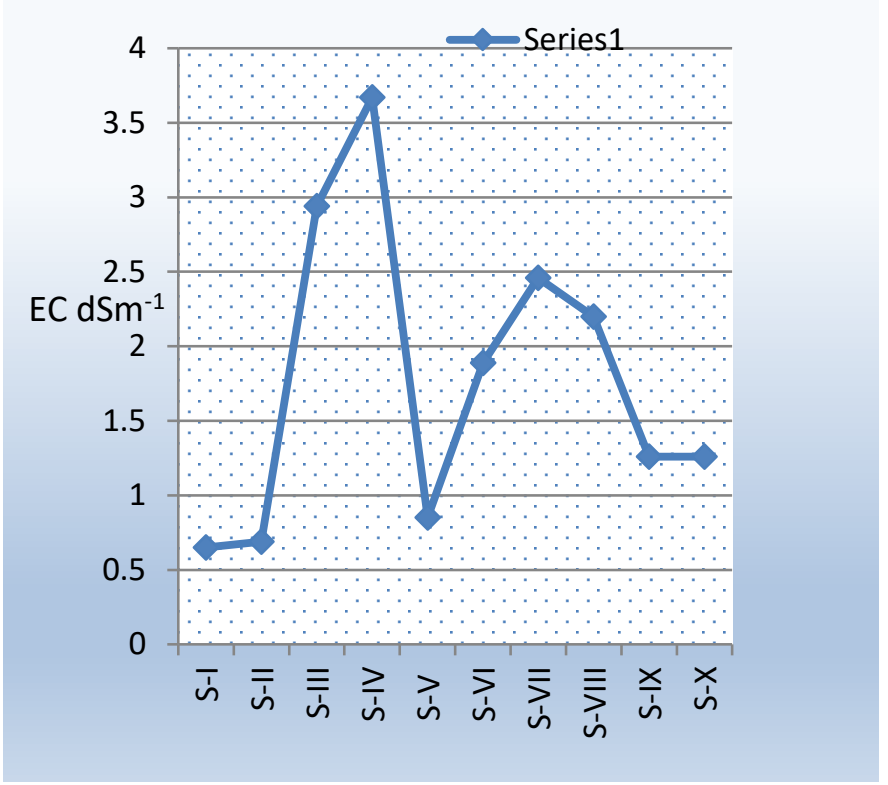

\section{Total Dissolved solid}

The highest total dissolved solids value were found in a water sample collected from S-IV (2348.8 mgl-1) and S-III (1883.0) while the water . The quantity of TDS was proportional to the degree of pollution( Rain et .al. 1990, Nasrullah 2006).

Samples collected from S-I ,S-II, S-V lower in order i.e. $416,443.73, \mathrm{mg}-1$ The TDS values at ten sampling sites are shown in fig 4 . The higher dissolved solid was due to excess use of irrigation water in irrigation area. This is because of addition of solids from open domestic sewage ,agriculture runoff sewage coming from sewage pipes and untreated or inadequately treated effluent discharged from different types of industrial units. The TDS values at ten sampling sites are shown in fig 4. WHO, BIS , ISI, and ICMR 
proposed a desirable range of $500 \mathrm{mg} / \mathrm{L}$ for TDS of drinking water. The TDS value are greater than 544 $\mathrm{mg} / \mathrm{L}$ except S-I and S-II sites.

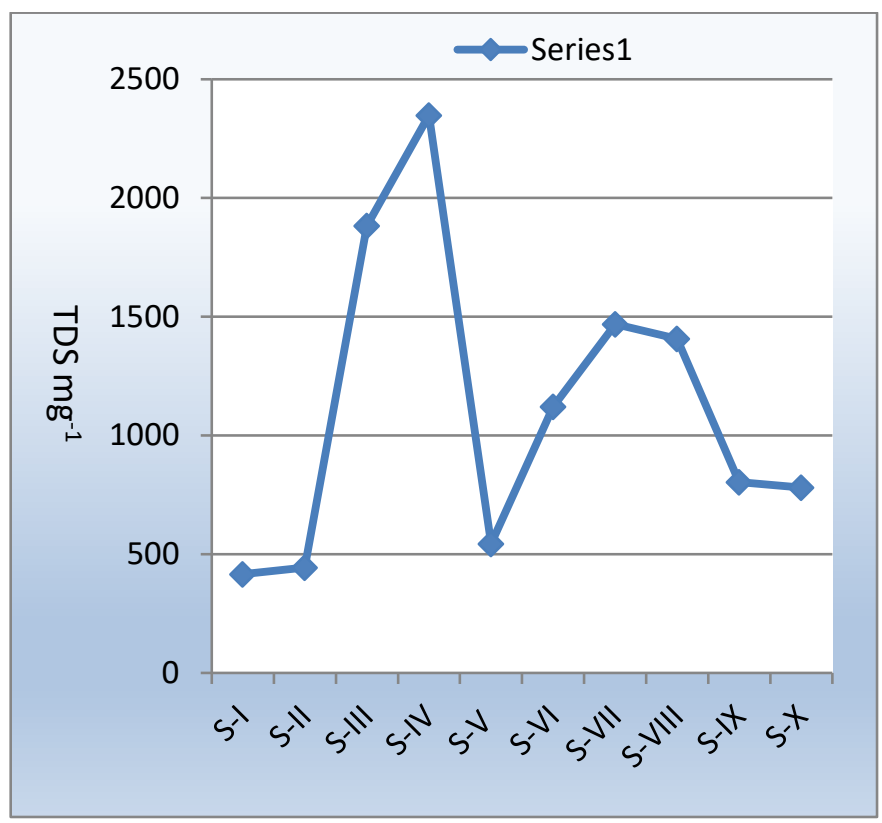

\section{Alkalinity (Carbonate and bicarbonate)}

Alkalinity is due to the presence of bicarbonate ,carbonate which dissolve in water from soil. WHO, BIS , ISI, and ICMR proposed a desirable range of Alkalinity of drinking water.

The carbonates were absent in the irrigation water from all the water samples of experimentation.

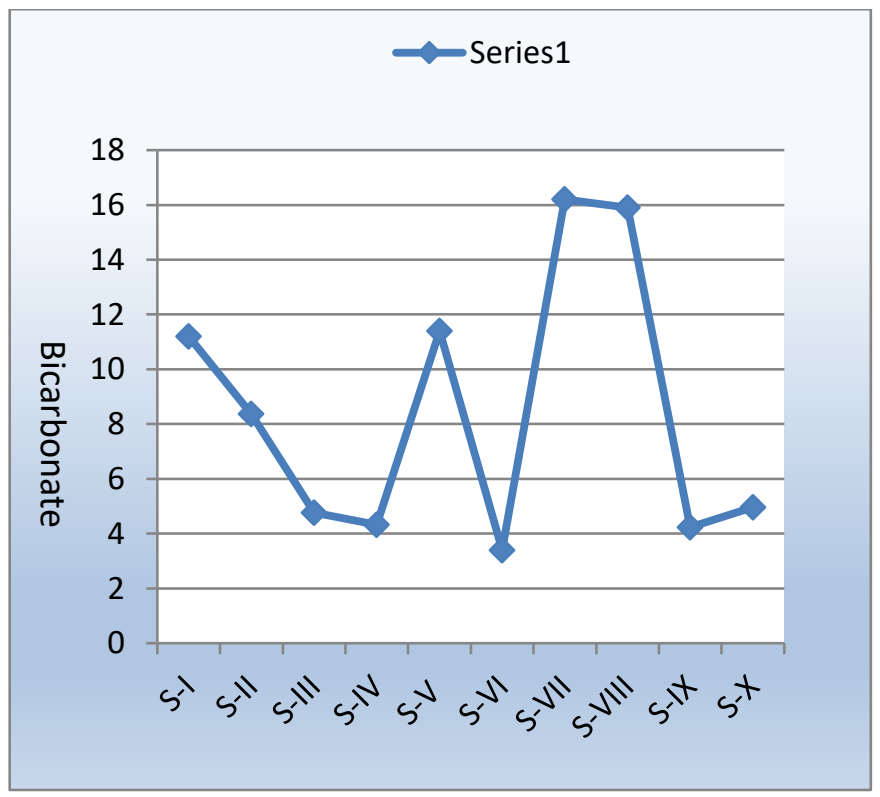

\section{Calcium Hardness}

Calcium is play important role in bone structure ,blood clotting . Some $99 \%$ of body calcium is in the bone, which 40\% calcium ( WHO 2009) However ,values exceeding $25 \mathrm{mg} / \mathrm{l}$ of calcium in drinking water have human health implication, according to WHO 2004 guideline. The calcium values at ten sampling sites are shown in fig 5 .

The highest calcium value was found in water sample collected from S-V, which was $11.43 \mathrm{me}^{-1}$ but the water sample collected from S-I,S-II and S-III were lower in order shows 7.63,8.36, and $7.06 \mathrm{me}^{-1}$ respectively. WHO, BIS , ISI, and ICMR proposed a desirable range of $75 \mathrm{mg} / \mathrm{L}$ for calcium hardness of drinking water. The calcium hardness value at all the sources of well within the WHO, BIS , ISI, and ICMR desirable limits.

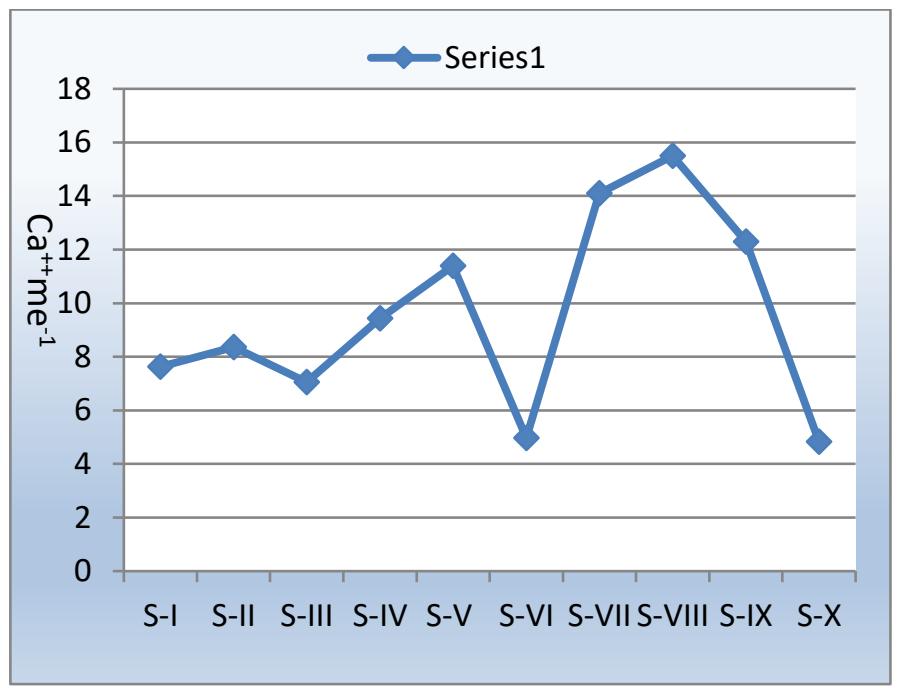

\section{Magnesium}

The highest magnesium value was found in water sample collected from S-I which was $12.33 \mathrm{me}^{-1}$ but the water sample collected from, S-III, S-IV and S-V are lower order showed that 7.43,7.93, and 4.53 me${ }^{1}$ respectively. The lowest magnesium value from S-II is $3.33 \mathrm{me}^{-1}$. The magnesium values at ten sampling sites are shown in fig 6 . 


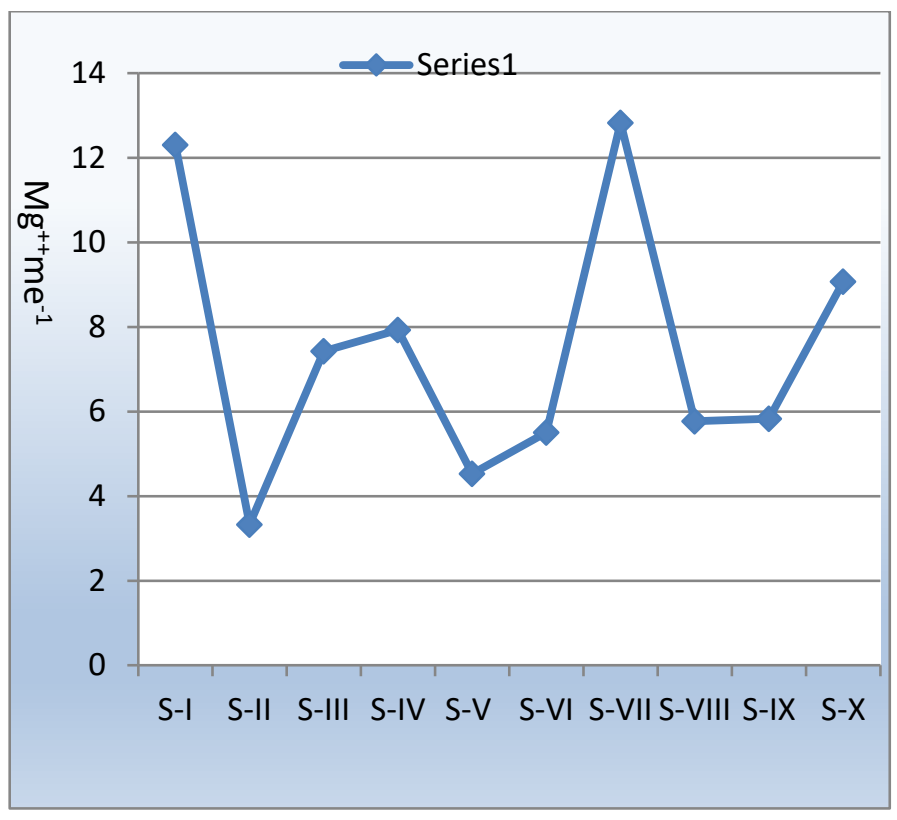

The total hardness is mainly due to $\mathrm{Ca}, \mathrm{Mg}$ ( Sharma 2001, De1994).The water containing excess hardness is not desirable for potable water. WHO, BIS , ISI, and ICMR proposed a desirable range of total hardness of drinking water. Total hardness values all the sources of well with in the WHO, BIS , ISI, and ICMR desirable limits.

The highest chloride value was found the water sample collected from S-IV , which was $35.3 \mathrm{me}^{-1}$ but the water sample collected from S-I , S-II ,S-III and S$\mathrm{V}$ are lower in order shows that $13.8,9.36,18.6,14.7$ me- ${ }^{-1}$ respectively

Sodium is essential element require for normal body function including muscle contraction and relaxation how ever in excess amount of sodium increases individual risk of hyper tension, heart disease. The highest sodium content was found in a water sample collected from S-III and S-IV , which is 39.19, 39.87 me- ${ }^{-1}$ But S-I and S-II are lower order shows 9.86 and $12.19 \mathrm{me}^{-1}$.
The calcium, magnesium, sodium, and chlorides of water from area were within safe limit. So the water from the collection centre is fit for drinking purpose.

\section{IV.CONCLUSION}

Water must not be used for drinking purposes without proper treatment. The Pravara river is one of the most important river of Sangamner that city. The sources of pollutants are local open domestic sewage, sewage coming through sewerage pipes, agricultural runoff containing fertilizers, pesticides, and insecticides. The physicochemical parameters $(\mathrm{pH}$, temperature, turbidity, colour total dissolved solids (TDS) ,carbonate, calcium hardness magnesium, and alkalinity) at all the sampling sites in the study area were within the limits. Recommendation of drinking water is drainage lines are laid on the opposite sides of the river to avoid pollution and Water must not be used for drinking and irrigation purposes without proper treatment.

\section{REFERENCES}

[1]. Agrarwal A, SaxenaM, 2011. Assessment of pollution by physicochemical water parameters. Advanced applied science research vol.2(2) pp185-1891.

[2]. APHA. 1989. Standard methods for the examination of water and waste water, American Public Health Association, Washington ,America.

[3]. APHA, AWWA and WPCF. 1995. Standard methods for the examination of water and waste water, 16th Edition, ,

[4]. APHA.1998. Standard methods for the examination of water and waste water, AWWA and WPCF, Washington ,America

[5]. BIS IS 10500,1991.Standard parameters given by Government of India, New Delhi, India. 
[6]. BIS IS 10500,2004. Standard parameters given by Government of India, New Delhi, India.

[7]. BIS IS 10500, 2005. Standard parameters of drinking water given by Government of India, New Delhi, India.

[8]. BK Sharma, 2001. Industrial Chemistry, Goel publishing house Meerut, India.

[9]. De AK, 1994. Environment Chemistry ( III edu), New Delhi, India

[10]. Gupta, I.C. 1999. Evalution of quality of irrigation waters and industrial effluents discharged on land for irrigation. J.Indian water works association: pp 47-56.

[11]. Kanwar, J.S. and Mehta, K. K. 1970. Quality of well waters and its effect on soil properties. Indian J. Agric. Sci. 40: 251-258.

[12]. Malik Dinkar ,2015. Assessment of water quality at Paon Dholi river during monsoon and after season ,Saharpur (U.P.) .Int.J. Phy\& App. Sci.vol5(3) pp 92-102.

[13]. Nasrullah, Rafia Naz, Hamida Bibi, Mudassar Iqbal, IIyas Durrani M. 2006. Inadequately treated effluent discharged from several types of Industrial units. Journal of Agricultural and Biological Science. Vol 1(3) pp 18

[14]. Pawar, N. J. 1993. Geochemistry of carbonate precipitation from the groundwaters in basaltic aquifers, an equilibrium thermodynamic approach. J. Geol. Soc. India. 41: 119 - 131.

[15]. Pawar, N. J., Pondhe, G. M. and Patil, S. F. 1998. Groundwater pollution due to sugar mill effluents at Sonai, Maharashtra, India. Environ. Geol. 34:151- 158

[16]. Rain FH. ,Thatcher L.L. 1990. Methods for collection and analysis of water samples U.S. Govt. Office Washinton,America.

[17]. Trivedy, R.K. and Goel, P. K. 1984. Chemical and biological method for water pollution studies. Environmental publi. Karad.

[18]. WHO, 1979. Sodium chloride and conductivity in drinking water. Report on a WHO working
Group. Compenhegan, Euro reports and studies No 2.

[19]. WHO,1984 Guidelines for drinking water quality ,vol.1, Recommendations WHO,Geneva,Switzerland.

[20]. WHO, 2004. Guidelines for drinking water Second Edition WHO, Geneva, Switzerland.pp 224-230

[21]. WHO,2009. Calcium and Magnesium in drinking water, Publication health significance, Geneva, Switzerland. pp 276

\section{Cite this article as :}

Dr. Sangita Dandwate, "Physico-chemical Analysis of Pravara River water and its Impact on Human Health in Sangamner Tahashil (Maharashtra)", International Journal of Scientific Research in Science and Technology (IJSRST), Online ISSN : 2395-602X, Print ISSN : 2395-6011, Volume 7 Issue 6, pp. 358-365, November-December 2020. Available at doi : https://doi.org/10.32628/IJSRST207656 Journal URL : http://ijsrst.com/IJSRST207656 